\title{
And then there was one: The Basel merger
}

Ciba (Basel, Switzerland) and Sandoz (Basel) have unveiled plans to merge into the world's largest life sciences group. The two Swiss companies took the market-and their own employees-by surprise when they announced their intention to conduct what is possibly the world's biggest corporate merger and certainly the largest life sciences merger and create a newly christened entity, Novartis. The deal has been estimated to be worth some $\$ 27$ billion.

Novartis plans to focus on its core life sciences businesses: pharmaceuticals, agrochemicals and seeds, and nutrition. It intends to spin off Ciba's specialty chemicals business and the Sandoz construction chemicals operations. Based on recently released 1995 figures, the combined company will have annual sales worth SF26 billion ( $\$ 21.7$ billion) after divestment of the specialty chemicals sector.

Although billed as a merger of equals, the proposed deal leaves Sandoz shareholders with a 55\% stake and Ciba shareholders $45 \%$. Of the overall anticipated sales of $\$ 21.7$ billion, health-care products will account for $59 \%$ of its business, agrochemicals $27 \%$, and nutrition $14 \%$. The company is expected to employ about 120,000 people worldwide. This means a loss of about 13,000 jobs$10 \%$ of the current Ciba and Sandoz labor forces--over the next three years.

Novartis will immediately take top positions in the leading life science markets.

In pharmaceutical sales, it will be the world's second largest company after Glaxo Wellcome (London), but ahead of Merck Sharp \& Dohme (Rahway, NJ), Hoechst Marion Roussel (Frankfurt, Germany) and Bristol Myers Squibb (Princeton, NJ). Combined health-care sales in 1995 were SF15 billion ( $\$ 12.5$ billion).

In crop protection and pest control, the combined firm will be able to build on Ciba's number one position in the world marketSandoz was not in the top ten-with joint sales of around SF5 billion ( $\$ 4.2$ billion). Sandoz has been seeking critical mass for its agrochemical business throughout the 1990s: It nearly merged in this area with Schering AG (Berlin) but the deal fell through, leaving Schering to form AgrEvo with Hoechst (Frankfurt, Germany).

In the seeds sector, the combined sales of SF1.1 billion ( $\$ 0.9$ billion) will create the world's second largest business-after Pioneer Hi-Bred (Des Moines, II.).

With total sales of SF0.9 billion ( $\$ 0.75$ billion), a similar global ranking will be

Mike Ward is a freelance writer working in Oxford, UK. achieved with the combination of both companies' animal-health businesses.

Another tier for the new company will be its nutrition business, which would have posted sales of SF3.7 billion ( $\$ 3.1$ billion) in 1995. Novartis will be Europe's largest healthfood producer and the number two company in the world medical nutrition market.

Yet it is not the synergies of the existing businesses that persuaded the two companies

\begin{tabular}{lr} 
Novartis' hypothetical place in the \\
1995 sales universe (Sbillion) \\
\hline Company
\end{tabular}

- Based on combined Ciba/Sandoz 1995 sales figures

to fuse, but the synergies that remain unlocked. Commenting on the move, Daniel Vasella, CEO of Sandoz Pharmaceuticals and future president of Novartis remarked; "There is a superb strategic fit between our two companies which intensifies our market power and unlocks resources for further expansion. Our clear lead in emerging therapies and our pipeline of unique compounds offers rapid and promising growth prospects." The importance of biotechnology expertise to the future of the pharmaceutical industry is reflected in mainstream business commentaries on the Novartis merger, which have focused heavily on the biotechnology relationships between the two companies.

Both Ciba and Sandoz have been very active in both the internal and external development of their biotechnology expertise. Ciba acquired $49.9 \%$ of Chiron (Emeryville, CA) in 1994 for $\$ 2.1$ billion and then used
Chiron to "sub-acquire" other business such as Viagene (San Diego, CA). Sando $z$ has made some spectacular (some would say questionable) acquisitions, buying $60 \%$ of SyStemix (Palo Alto, CA) for $\$ 392$ million in 1991 (and another 12\% for $\$ 80$ million 1995), and Genetic Therapy Inc. (Gaithersburg, MD) for $\$ 295$ million last July.

In gene and cell therapy, Novartis will have access to expertise developed at Chiron, GTI, SyStemix, and Viagene (San Diego, CA). Novartis has strong intellectual property positions that embrace both in vivo and ex vivo gene therapy. Sandoz brings to the table its xenotransplantation and immunology portfolio, including relationships with BioTransplant (Charlestown, MA), Imutran (Cambridge, UK), Procept (Cambridge, MA), Harvard College (Cambridge, MA), and the Vienna International Research Cooperation Center (Vienna, Austria). In drug discovery, Novartis will have access to the combinatorial chemistry expertise of both Chiron and Pharmacopeia (Princeton, NJ), and to the genomics data that is expected to emerge from Ciba's 1995 five-year collaboration with Myriad Genetics (Salt Lake City, UT), which focuses on gene-linked cardiovascular diseases. Novartis "is at the forefront of gene sequencing," the company claims, because of more than a dozen collaborations with academic research institutions, including the Whitehead/MIT Center for Genome Research (Cambridge, MA), the Stanford Human Genome Center (Palo Alto, CA), the Johns and Hopkins Consortium (Baltimore, MD), the Max Planck Institute (Berlin, Germany).

Novartis will also emerge as one of the major players in the development of agricultural biotechnology. The company's seed product line includes high-value-added varieties in corn, oilseeds, sugar beet, vegetables, and flowers. It will have one of the broadest investments in breeding and a substantial germplasm base, as well as one of the largest and most focused biotechnology research commitments. Novartis will be looking to roll out maize resistant to the European corn borer, while continuing to engineer both disease and insect resistance into other crops.

Through equity holdings and research and development collaborations made in the past 5 years, Novartis will have links with more than 20 biotechnology companies. And it seems unlikely that Novartis will abandon active biopartnering. Daniel Vasella was a strong advocate within Sandoz of external relationships: Almost one-third of Sandoz's resources were devoted to external activities. And now the combined company has SF15 billion ( $\$ 12.5$ billion) in liquid assets to play with.

Mike Ward 